\title{
THE SASKATCHEWAN NATURAL HISTORY SOCIETY
}

BOARD OF DIRECTORS (October, 1970, to October, 1971

onorary President............ Robert D. Symons, Silton, Saskatchewan

resident

Gordon Silversides, 1201 Grace Street, Moose Jaw

ast President

W. A. Brownlee, 3628 Mason Avenue, Regina

irst Vice-President

J. A. Wedgwood, 610 Leslie Avenue, Saskatoon

Margaret Belcher, 2601 Winnipeg Street, Regina

George R. Dodd, 33 Malone Crescent, Regina

Patricia Kern, 1053 Chestnut Street, Moose Jaw

Marie Gillespie, 221 Eleventh Street E., Saskatoon

reasurer

orresponding Secretary $\ldots$

ecording Secretary

\section{SPRESENTATIVES AT LARGE}

Ron Austin, Prince Albert; Harvey Beck, Calgary; Al Binnie, Regina; Tom entles, Regina; Donald Hayward, Wolseley; Ernie Kuyt, Fort Smith, N.W.T.; ack McKenzie, Regina; Murdoch Nelson, Moose Jaw; Frank Roy, Saskatoon; harles Shulver, Lafleche; Mary Skinner, Indian Head; Mrs. Sylvia Van Brienen, osetown.

\section{RESIDENTS OF LOCAL NATURAL HISTORY SOCIETIES}

Mrs. D. Bromey, Maple Creek; Carl Ellis, Moose Jaw; To be named, Prince lbert; J. K. Roberts, Regina; Maureen Rever, Saskatoon; Dr. Jan Looman, wift Current; Bill Gibson, Yorkton.

\section{PPOINTED DIRECTORS}

Blue Jay Archives: Gary Seib, 1928 Robinson Street, Regina; Blue Jay ookshop: Frank Brazier, 2657 Cameron Street, Regina; Circulation: Lorne cott, Saskatchewan Museum of Natural History, Regina; Editor of Newsletter: ames Slimmon, 2526 Hanover Avenue, Saskatoon; Local Societies: James Jedgwood, 610 Leslie Avenue, Saskatoon; Office Services: James Jowsey, 2635 ineteenth Avenue, Regina; Publicity: Rose McLaughlin, Indian Head; Special ublications: C. Stuart Houston, 863 University Drive, Saskatoon; Youth: rank Switzer, 140 Logan Crescent, Yorkton.

\section{HE BLUE JAY}

Blue Jay Editors: George F. Ledingham; Assistant Editors: Margaret elcher, Robert W. Nero; Junior Naturalists : Joyce Deutscher.

All items for publication should be submitted to George F. Ledingham, ditor, 2335 Athol Street, Regina.

\section{SUBSCRIPTION-MEMBERSHIPS}

The classes of memberships in the SNHS are as follows: Regular, $\$ 3.00$; upporting, $\$ 5.00$; Sustaining $\$ 10.00$. Bulk orders (minimum of five to one ddress) are available to junior club members and to educational institutions at le rate of $\$ 3.00$ for the first subscription and $\$ 1.00$ for each additional one.

Send all renewals and new memberships to THE TREASURER, SNHS, ox 1321, Regina, Saskatchewan. (Note: Bookshop orders and general inquiries pould be sent to Box 1121.)

\section{REPRINTS}

Requests for quantities of reprints of any article printed in the Blue Jay lould be sent to Printcraft Ltd., Regina, Sask., within one month of publicaon. Contributors wishing a few extra copies of the current Blue Jay may et them at cost. Requests for these should be made to the Editor when material submitted for publication. 